\title{
Por uma atenção distraída: estudos sobre a percepção na preparação do ator
}

Ana Caldas Lewinsohn

\author{
Universidade Federal do Rio Grande do Norte
}

\begin{abstract}
Resumo
Esse texto aborda algumas experiências práticas para discutir aspectos sobre a percepção e atenção no território da preparação do ator. A partir de uma compreensão sobre a noção de um brincar a sério, verificamos a potência de habitar em cena paradoxos como a liberdade e o limite, o trânsito entre o consciente e o inconsciente e a integração mente e corpo.
\end{abstract}

Palavras-chave: Preparação do ator. Atenção. Brincar. Percepção.

Que eu me organizando posso desorganizar Que eu desorganizando posso me organizar

Da lama ao caos, Chico Science e Nação Zumbi

Quando estamos em sala de ensaio, sala de treinamento, sala de aula, sala de criação teatral, lidamos com diversas forças que permeiam o tempo/espaço e atravessam os corpos atuantes de forma sempre imprevisível. O fator intrínseco à arte presencial de estar exposta ao risco do inesperado e, portanto, nada nunca assegurado, faz com que seja necessário um estado de atenção e percepção desenvolvidos para o jogo e a brincadeira com o acaso.

Nos diferentes estilos e linguagens que podem ser modelados, moldadas e forjados para compor formas espetaculares, nos interessa, nesse estudo, aquilo que perpassa os corpos em fluxo e nomeamos de vida, ou presença, ou organicidade. Aquilo que é invisível e impalpável, porém absolutamente perceptível para quem age e para quem vê. No intuito de investigar os meandros da atuação no campo da preparação e buscar compreender do que é feito esse estado de presença, realizei algumas observações e vivências de dispositivos de provocação cênica que serão relatados e discutidos a seguir.

Entre os anos de 2010 e 2013 acompanhei três grupos de teatro, no intuito de compreender um pouco sobre seus processos pedagógicos e de criação, observando a 
maneira como os diretores e/ou professores das práticas realizavam indicações para os atuantes. A intenção era verificar os momentos nos quais as performances, cenas e exercícios, ficavam vivos, orgânicos e presentes: sob quais tipos de provocações pelos condutores do trabalho? Sob quais condições e situações? Assim, por meio da observação dos grupos Lume Teatro (Campinas, SP), Familie Flöz (Berlim, Alemanha) e Teatro da Vertigem (São Paulo, SP), realizei uma vasta coleta de material composta de anotações de todas as palavras pronunciadas pelos diretores/professores nesses coletivos, além de registros em vídeo e entrevistas ${ }^{1}$.

Cada sala de ensaio, cada grupo e processo de criação utiliza, em suas práticas, o que podemos chamar de metáforas de trabalho. As metáforas de trabalho são ideias, ações, imagens, comandos verbais utilizados em práticas de ensaio, aulas ou processos criativos para auxiliarem os atuantes a entrarem em um estado de experimentação. A utilização de metáforas de trabalho em práticas teatrais possibilita a construção de um corpo-em-arte, gerando e potencializando estados de criação, repetição, atualização e manutenção de ações-matrizes físico-vocais no contexto poético ficcional e espetacular. Essa pesquisa investiga a potência dessas provocações, na busca de criar uma relação mais íntima entre conceitos e a prática artística, e de uma reflexão teórica cada vez mais próxima do processo criativo, utilizando seus paradigmas, sua linguagem e terminologia para discutir questões pertinentes sobre o trabalho do ator contemporâneo.

Um dos fatos que observei, ao vivenciar acontecimentos para essa pesquisa ${ }^{2}$, foi o uso de metáforas de trabalho que buscavam provocar uma qualidade de atenção diferenciada para os exercícios ou cenas. A atenção, apesar de exigir concentração e rigor do ator, necessita, ao mesmo tempo, que o "elástico não esteja esticado demais", ou seja, que o foco não seja excessivo, que a seriedade e o empenho com o ato não sufoquem o fluxo, o espaço para pequenas doses do incerto, inacabado e impreciso. Trata-se de um potente paradoxo que irei discutir nesse texto a partir de alguns exemplos práticos, entremeados de reflexões e discussões conceituais.

\footnotetext{
1 A coleta de material compreendeu os seguintes acontecimentos. Com o grupo LUME Teatro, realizei o acompanhamento de três versões do workshop O Corpo como Fronteira, ministrado por Renato Ferracini. Participei deste curso em quatro situações diferentes: em 2004, em sua primeira versão, como participante da prática; em 2009, 2011 e 2012 como observadora; e, em 2015, como ministrante, junto à Renato Ferracini, na Universidade Nova de Lisboa (Portugal). Também junto ao LUME Teatro, realizei a observação de três semanas do processo de criação do espetáculo Os Bem Intencionados, com direção de Grace Passô (Campinas, 2012). Com o Teatro da Vertigem observei uma semana do processo de montagem do espetáculo Bom Retiro 958 metros, sob direção de Antônio Araújo (São Paulo, 2012). Com a Familie Flöz realizei a participação e observação do workshop Sommer Akademie, Perform with masks (Toscana, Itália, 2012). As entrevistas foram realizadas com Carlos Simioni (LUME Teatro), Grace Passô (Grupo Espanca!), Hajo Schüler e Michael Vogel (Familie Flöz) e Antônio Araújo (Teatro da Vertigem).

${ }^{2}$ A pesquisa foi realizada em equipe, ancorada no LUME Teatro (Núcleo Interdisciplinar de Pesquisas Teatrais da UNICAMP), no projeto temático Memória(s) e Pequenas Percepções, coordenado por Renato Ferracini, de 2010 a 2014. O texto desse artigo é parte da minha tese de Doutorado, resultado dessa pesquisa, intitulada Metáforas de trabalho em territórios de criação: provocações do corpo-em-arte na preparação do ator, 2014.
} 
Trata-se também de assumir o imponderável, o indizível, o espaço entre. Aceitar também o medo da morte, do fracasso, do vazio, a tentação que temos de nos agarrar à segurança e ao conforto, a tentativa vã de estabilidade e de equilíbrio. Conviver com todas as forças que permeiam a criação artística e o território de preparação, sejam elas propensas à estabilidade ou à instabilidade. Aceitar nossa condição de errante, de viajantes sem rumo prédeterminado, de corpos frágeis e por isso vivos. Faço minhas as perguntas de Peter Pál Pelbart (2007):

Como então preservar a capacidade de ser afetado, senão através de uma permeabilidade, uma passividade, até mesmo uma fraqueza? Mas como ter a força de estar à altura de sua fraqueza, ao invés de permanecer na fraqueza de cultivar apenas a força? (PELBART, 2007, p. 30).

Aceitemos, pois, que o que nos resta é brincar com nossa "patética" necessidade de estabilidade. Assumamos nossa impermanência. Lembremos que a morte, como disse Eduardo Viveiros de Castro (2009), paradoxalmente, "é uma espécie de condição de possibilidade do acontecimento" 3 . Ou, como afirma o dançarino de butô Kazuo Ohno:

A arte é sempre profundamente relacionada com a vida e a morte, a alma e o corpo. Algumas vezes é impossível ao pensamento lógico compreender isso. A arte tenta desvendar o mistério de viver e morrer. (OHNO, s.d.).

No nosso caso, na prática das Artes Cênicas, o corpo é o território potencial no qual temos a possibilidade de problematizar e explorar ainda mais as questões nãodimensionáveis expostas acima, dos paradoxos que nos assombram e, ao mesmo tempo, nos mobilizam e instigam a criação, como por exemplo os binômios de vida/morte, força/fraqueza, equilíbrio/desequilíbrio, dentro/fora entre tantos outros ${ }^{4}$. Façamos então do nosso corpo um território de experimentação da vida/arte, espaço de recomposição e reagenciamentos das forças que nos atravessam. É sempre hora de reinventar tudo, desde que seja uma ação direcionada para nos tornar mais permeáveis na capacidade de afetar e ser afetado, na potência dos encontros.

\footnotetext{
${ }^{3} \mathrm{O}$ antropólogo Eduardo Viveiros de Castro, na palestra intitulada $A$ morte como quase acontecimento, apresenta uma reflexão sobre o modo singular como algumas sociedades indígenas lidam com a morte. No decorrer de sua fala, demonstra como, no decorrer da história do ocidente, o momento real da morte deixou seu caráter público e social para se tornar algo privado, íntimo, quase um "tabu". O medo que temos da morte enquanto única ação inevitável da vida, muito tem a ver com esse processo histórico. "A morte é fundamental para que a noção de acontecimento se constitua. Então ela tem esse caráter paradoxal, ela é ao mesmo tempo um nada, uma coisa que não acontece a nós, e ao mesmo tempo ela é a única coisa que a gente sabe que acontece e que torna o acontecimento possível. Então a morte é uma espécie de condição de possibilidade do acontecimento". (VIVEIROS DE CASTRO, 2009).

${ }^{4}$ Como um aprofundamento dessa relação paradoxal das forças, realizei, em 2016 e 2017, a pesquisa de pósdoutorado $O$ paradoxo morte-vida na presença do ator, na qual investiguei uma necessidade do vazio a partir do estudo de filosofia e práticas contemplativas como a yoga e a meditação. Um dos resultados pode ser verificado no artigo publicado na Universidade de Huddersfield, Inglaterra (LEWINSOHN, 2019).
} 
A vida e o corpo são, no fundo, uma mesma coisa. Mas para que assim seja, é preciso descobrir o corpo dentro de sua própria força de gênese, porque o corpo é esse lugar existencial e ainda por cima político, no qual se empilham, se encolhem, se dobram, todas as determinações da vida. É o campo de batalha onde se cruzam as forças visíveis e invisíveis, a vida e a morte e onde se encadeiam as redes, os poderes, os tráficos. (UNO, 2007, p. 51).

Kuniichi Uno (2007) diz sobre uma força de gênese própria a cada um, em referência à luta de Artaud (1999) por um renascimento do próprio corpo, auto-gerado, uma recriação constante e reorganização do que nasceu, biologicamente, de uma determinada maneira, mesmo tendo em vista a influência de contextos sociais, históricos, culturais, ambientais e políticos específicos. É por reconhecer as forças que atuam mesmo contra a nossa vontade, que faz-se a necessidade de resistir, como re-existência, re-concepção do próprio corpo com autonomia. Nesse sentido, a arte adquire uma potência de recriação das formas de existir.

Nessa discussão, o modo como nos colocamos diante e inseridos em nossa prática, é imprescindível para compreendermos a possibilidade da criação de espaços abertos para o afeto em nossos corpos. Para conversarmos um pouco sobre a qualidade da atenção mencionada acima, é interessante relatar alguns detalhes da experiência e convivência com a Familie Flöz, pois, acredito que, às vezes, as entrelinhas - aquilo que não é exatamente preparado para atuar como elemento pedagógico - acabam contribuindo, também, de forma significativa para uma ampliação ou redimensionamento do olhar sobre o próprio fazer/atuar.

O workshop VI Flöz Akademie, Perform with Masks foi realizado em um mosteiro na Toscana (Itália), no qual todos os participantes (alunos) e integrantes do grupo (professores), permaneceram por 15 dias em intensa convivência ${ }^{5}$. Dois dos integrantes do grupo, Hajo Schüler e Michael Vogel, diretor da Flöz, foram meus professores, o primeiro durante o período de manhã e o segundo à tarde.

A primeira situação que me chamou a atenção, foi o fato das famílias dos atores do grupo estarem o tempo todo ao nosso lado, em convívio contínuo, antes, durante e após o trabalho, havendo, assim, um trânsito espontâneo das crianças durante as aulas. A naturalidade com que os atores/professores lidam com a presença e ausência das crianças, cria um ambiente de descontração, muito diferente das situações mais rígidas com as quais havia me deparado em workshops ou em trabalho de outros grupos no Brasil. As crianças

\footnotetext{
5 Trinta alunos, além dos professores (integrantes da Familie Flöz e seus familiares), se hospedaram no mosteiro de 900 anos, que não era utilizado há 600 anos desde que os monges deixaram o local. Lá, tivemos uma intensa convivência (24 de junho a 07 de julho de 2012), onde, além do curso que participávamos no dia inteiro, dormíamos e comíamos juntos e assim compartilhamos uma experiência memorável de 15 dias. Tínhamos uma rotina préestabelecida e que era seguida diariamente: das $6 \mathrm{~h} 30$ às $8 \mathrm{~h}$ da manhã, para os interessados, aula de yoga (da qual participei); das $8 \mathrm{~h}$ às $9 \mathrm{~h}$, café-da-manhã; das 9 às $13 \mathrm{~h}$, todo o grupo junto para aulas de dança, preparação corporal, jogos e trabalho com máscara neutra (conduzido pelo ator Hajo Schüler); das $13 \mathrm{~h} 30$ às 14h30, almoço; das $14 \mathrm{~h} 30$ às $16 \mathrm{~h}$, pausa; das $16 \mathrm{~h}$ às $19 \mathrm{~h} 30$ o grupo se dividia em 3 coletivos de 10 integrantes cada: o primeiro trabalhava confecção de máscaras; o segundo, performance com máscaras; e o terceiro, desenvolvimento de personagens e cenas com máscaras. Eu participei do terceiro, com o ator e diretor da Famile Flöz, Michael Vogel. Além de realizar entrevistas com Michael Vogel e Hajo Schüler, pude registrar em diário de campo e em vídeo, diversos trechos de indicações de exercícios e direção de cenas.
} 
entram na sala, assistem, às vezes invadem as cenas, improvisam, e chegaram, inclusive, a preparar uma oficina de dança breake para os interessados.

Após essa experiência, pude entender que uma certa descontração e o ambiente familiar que permeou todo o workshop, apenas refletia um dos aspectos significativos do trabalho da Familie Flöz: o prazer, a brincadeira, a entrega, a vontade e o gosto pelo que fazem. Esse aspecto do prazer, que guia os direcionamentos dos workshops do grupo, como também de seus processos criativos, é elemento fundamental para que continuem ou não realizando determinado exercício, improviso ou cena e se (re)alimentem desses movimentos.

Um dos exercícios realizados no workshop, por exemplo, é a ação de criar jogos, brincadeiras. Os alunos são separados em pequenos grupos de cinco ou seis pessoas. A partir daí, cada núcleo precisa criar uma brincadeira com regras claras, para que o público possa entender, desde que seja divertida para se jogar e para se assistir. Essa é uma forma utilizada inclusive para a criação de cenas de espetáculo da companhia. Assim como qualquer peça de teatro não deixa de ser um jogo, uma brincadeira, um faz-de-conta, a ideia é estar sempre em busca desse estado, que muitas vezes se perde pela seriedade que permeia os trabalhos, como demonstra o ator Hajo Schüler:

A coisa ideal seria que você pudesse fazer acontecer tudo em jogos, eu acredito. Então, que você não pare de brincar, isso seria o ideal. Que você nunca dissesse "ok, agora eu vou fazer um exercício sério". Isso é o que eu adoro no jeito de XXX* ["nome não compreendido na transcrição] por exemplo, quando ele faz todo o treinamento com figurinos, sabe? Você se sente tão estúpido de fazer esse exercício e é exatamente para isso que ele é feito. Porque o único valor desse exercício é quando você o experiencia, e você não o leva como um exercício sério, de algum modo, sabe? Porque nenhum exercício é sério, porque o exercício é o modo como você o realiza, é a qualidade de percepção, do prazer que você tem, ou da relação entre você e o exercício. Então é isso que tem que ser treinado, de algum modo, não o exercício, ele não tem valor algum. Quando você aceita isso, eu acho, ele começa a ficar interessante, porque não importa, no fim. Então, não há certo ou errado, não existe uma verdade que você tenta alcançar. [...] É de um jeito subversivo [...], é um pouco anarquista, não tem sentido algum, porque é só um jogo. E isso é o teatro também, é algo parecido, é um jogo de convenção, você brinca, todos sabem que em um determinado momento o teatro acaba e você vai para fora em sua vida real. [...] E é importante para nos lembrar, eu acho, que nós estamos brincando, que nós não levemos tão a sério. ${ }^{6}$ (Trecho de entrevista concedida em julho de 2012 por Hajo Schüler. Grifos meus).

\footnotetext{
${ }^{6}$ Tradução minha: For me, the ideal thing would be to make all in games. So, to invent so many games that nearly everything that you lean, or to, I don't know, to techniques that you have a common language in a way, you know? The ideal thing would be that you can everything make happen in games, I think. So, that you don't stop play, this would be the ideal. That you never go 'ok, now I do a serious exercise'. This is what I adore in the way XXX, for example, when he makes the whole training in costume, you know? You feel so stupid to make this exercise and this is exactly what it's for. Because the only value of this exercise is when you experience it, and you don't take as a serious exercise in a way, you know? Because no exercise is serious, because it's the way you do it, it's the quality of awareness, of fun that you have, or the relationship between you and the exercise it's the exercise. So, this is that has to be trained in a way, not the exercise, has no value, it has no value. When you accept this, I think, it becomes interesting, because it doesn't matter in the end. So, there is no right or wrong, there is not the truth that you try to achieve [...]. [...] it's kind of subversive. [...] it's a little bit anarchy, have non-sense in it, so, because it's just a game. And this is theatre also, it's something like this, it's a convention of game, you play, everybody knows
} 
Vemos nas palavras de Hajo Schüler que a descontração, ou a brincadeira, não tira a responsabilidade ou o rigor com o qual se joga. Toda brincadeira é séria, mesmo as infantis, no sentido de que são vivenciadas com inteireza. Podemos notar nas crianças, quando brincam, que nenhuma parte delas está de fora, não estão divididas nem entre corpo/mente, nem entre passado/presente/futuro. Crianças são mestres em viver o presente do presente ${ }^{7}$ (FABIÃO, 2010). E quando crescemos, o presente do presente, que era naturalmente vivenciado na infância, se torna uma busca e desafio diário, não só quando estamos na prática de trabalho, mas a qualquer momento.

Talvez aquilo que Hajo Schüler queira dizer, seja que existe uma característica no brincar, que seria importante não abrirmos mão, pois determina a "qualidade de percepção, do prazer que você tem, ou da relação entre você e o exercício". É comum que, o fato de levarmos muito a sério nosso trabalho, como atores, professores, ou diretores, acabe, às vezes, ocultando, ou não priorizando, o prazer irrestrito, constitutivo e inerente ao jogo. Devemos, é claro, levar nosso trabalho a sério, porém, paradoxalmente, temos que relembrar, sempre, que trabalhamos com algo que não é sério. O teatro será sempre faz-de-conta, realidade inventada, brincadeira, jogo.

Faz parte do processo de ensaio, treinamento e da criação de espetáculo, o burilar, o empenho nos detalhes, o aprimoramento, a repetição exaustiva, tão necessários às artes da cena, porém às vezes não tão prazerosos como a arte de descobertas e do improviso. É importante ter um cuidado permanente, no entanto, para que um excesso de seriedade e rigor não excluam o prazer de se estar ali. Aqui. Comprometimento talvez seja um termo mais adequado para o envolvimento com aquilo que se faz. Esse comprometimento não pode estar pela metade, ou em parte. Mas a seriedade, ela existe na mesma medida em que a criança coloca uma capa vermelha amarrada em seu pescoço e leva a sério sua mutação, saindo correndo e gritando: "sou um super-homem". Ninguém vai questioná-la. Ela é: porquê crê, brinca e investe todo o seu ser na ação.

No brincar, o indivíduo, o espaço e possíveis objetos da brincadeira saem da esfera exclusivamente utilitária, e esta situação inclui diferentes graus de subjetividade. $O$ mundo interno das crianças emprega parâmetros de uma realidade percebida por ela, que não coincidem necessariamente com as leis que governam a materialidade do objeto externo. Os efeitos externos são atenuados e o objeto revela uma vitalidade mais profunda por seu calor subjetivo, pela interação imaginativa e corporal entre a criança e o objeto. Nesse justo momento há um relaxamento das

\footnotetext{
that, one moment this theatre it's over and you go out in real life. So, and this is the same when you play. And it's important to remind us, I think, that we are playing, that we don't take this too serious.

7 "O fluxo abre uma dimensão temporal: o presente do presente. A capacidade de conhecer e habitar este presente dobrado determina a presença do ator. Perder-se nos arredores do instante - na ansiedade do futuro do presente ou na dispersão do passado do presente - faz com que o agente se ausente de sua presença. A qualidade de presença do ator está associada à sua capacidade de encarnar o presente do presente, tempo da atenção. $O$ passado será evocado ou o futuro vislumbrado como formas do presente". (FABIÂO, 2010).
} 
defesas conscientes e se dão passos para experiências subjetivas que se encontram em níveis mais profundos, dissolvendo as divisões entre o que está dentro e o que está fora, comunicando a experiência do ser. O brincar opera nesta unidade subjetiva. O brincar, entendido como atitude do corpo e da mente, determina uma conduta pensante. (PEREIRA, 2002).

Apesar de estar discutindo o universo lúdico infantil, as palavras acima de Péo (Maria Amélia Pereira ${ }^{8}$ ) - grande estudiosa e praticante do brincar e das questões da infância poderiam, também, ser aplicadas ao contexto da criação teatral. Quantas vezes nos deparamos com exercícios e improvisações ou com a manipulação de objetos de cena de uma maneira inusitada, que desafiam as leis utilitárias, na criação de outra realidade? Da mesma maneira como Péo observa nas crianças, no caso dos atores, quando realizam suas ações com plenitude e estão vivos no jogo teatral, as defesas se diluem, corpos se encontram em uma inteireza de "atenção distraída", na qual não há divisão.

A expressão "conduta pensante", como uma atitude do corpo e da mente, nos remete, também, ao termo de Grotowski, "consciência orgânica":

É preciso se desembaraçar do medo, da desconfiança recíproca, suprimir a linha de divisão entre o que se faz e a reflexão sobre o que se faz; procurar como estar frente ao outro inteiramente, com todo o seu ser. (GROTOWSKI apud MOTTA LIMA, 2012, p. 242).

A consciência orgânica, [...] permitiria o acesso a esse 'si mesmo' todo, a esse 'si mesmo' não conduzido nem manipulado - e portanto, restrito - pelo intelecto. $O$ próprio intelecto passava a fazer parte - e era, portanto, reinventado - a partir e através da consciência orgânica. (MOTTA LIMA, 2012, p. 250).

Por mais que as duas noções tratem de esferas distintas - a criança, ao brincar e o adulto, ao atuar - podemos verificar semelhanças que podem nos ajudar a problematizar a questão que vem sendo debatida até agora. Parece que o brincar, a brincadeira, o jogo, o despojamento, o assumir o risco, pode ser um aspecto chave para aquilo que nomeio de uma "atenção distraída".

A atenção é necessária, a todo momento, ao realizar um exercício corporal, na performance em uma cena, no improviso, na precisão dos detalhes já delineados (corporalmente, verbalmente, de tempo, ritmo). Porém, a atenção a todos os componentes do

\footnotetext{
8 Péo foi minha professora no curso $A$ arte do brincante para educadores, no Instituto Brincante, em São Paulo (2003). A partir dela conheci a Casa Redonda, espaço criado há 30 anos por Péo, onde ela desenvolve, na prática, o livre brincar com crianças de 2 a 6 anos. Verificar o livro lançado em 2013, pela editora Livre Conteúdo e Cultura, Casa Redonda: uma experiência em educação. Verificar também a entrevista "Brincar é o último reduto de espontaneidade que a humanidade tem", na Revista Pátio Educação Infantil, ano I, número 3, com Lydia Hortélio, outra pessoa com quem tive contato no Brincante e me abriu os olhos para a importância do brincar e da música da cultura tradicional infantil brasileira. Apesar de parecerem universos distantes - a sala de trabalho da preparação do ator e as brincadeiras na infância - o contato com algumas reflexões sobre o brincar da criança me ajudaram a pensar sobre esse estado de "atenção distraída", ou sobre a presença e inteireza que almejamos quando estamos em cena. Talvez, há mais proximidade entre as duas esferas do que podemos imaginar, à primeira vista. Basta observar aberta e atentamente uma criança brincando, para nos darmos conta do quanto podemos aprender. O mundo todo ao nosso redor está nos dizendo e nos ensinando a cada momento, é uma questão de abrir o corpo para olhar (José Gil, 2004) e "dar língua para afetos que pedem passagem" (Suely Rolnik, 2011).
} 
jogo e da cena, não pode sofrer de uma rigidez - obstinada a fazer tudo certo - que acabe impedindo, paradoxalmente, o próprio jogo acontecer. Como afirma Virgínia Kastrup ${ }^{9}$, para uma atenção sensível (2010):

Informações, saberes e expectativas precisam ser deixados na porta de entrada, e o cartógrafo deve pautar-se sobretudo numa atenção sensível, para que possa, enfim, encontrar o que não conhecia, embora já estivesse ali, como virtualidade. (KASTRUP, 2010, p. 48-49).

Então, para que o teatro aconteça, as regras precisam ser seguidas, porém, se o objetivo for exclusivamente seguir as regras, o teatro não acontece. É na invisibilidade, no espaço micro, na relação dos corpos, no espaço entre, que a vida pode acontecer em um exercício, cena, improviso ou espetáculo. Trata-se portanto de uma disponibilidade para o imprevisto, um corpo aberto (Gil, 2004) que permita a água brotar e correr. Um corpo que se permita o prazer de brincar e dançar com as forças que compõem o ato cênico, que desfrute da sua dimensão de precariedade.

Abrir o corpo é, antes de mais, construir o espaço paradoxal, não empírico, do emredor do corpo próprio. Espaço paradoxal que constitui toda a textura da consciência do corpo-consciência: um espaço-à-espera de se conectar com outros corpos, que se abrem por sua vez formando ou não cadeias sem fim. (GIL, 2004).

Quando observei o processo criativo do Teatro da Vertigem, do espetáculo Bom Retiro 958 metros, em 2012, notei um aspecto curioso na forma de direção de Antônio Araújo. Vale observar que a montagem da peça ocorreu em um teatro abandonado, no bairro do Bom Retiro, em São Paulo, local que, das $19 \mathrm{~h}$ às $23 \mathrm{~h}$ da noite, era povoado por baratas, morcegos, muita sujeira, cheiros desagradáveis de lixo na porta de entrada, bem escuro, com pouca iluminação. Parte dos ensaios era também realizada nas ruas e nas calçadas, povoadas por outros insetos, líquidos de origens duvidosas no chão etc. Podemos dizer que não era exatamente um lugar "acolhedor". Todos esses fatores, entretanto, eram também forças que geravam atravessamentos e afetos na composição das cenas, sendo determinantes na qualidade e particularidade da atmosfera criada no espetáculo final.

Enfim, em meio a esse ambiente, Antônio Araújo revelou uma faceta de pitadas de humor, um certo "humor negro", em suas provocações. Creio que esse aspecto realizava um agenciamento interessante em meio ao território inóspito, instaurava um clima de brincadeira, um tanto "perverso" em certo sentido, que parecia combinar com o contexto e, mais importante, mostrou funcionar, gerar potência de vida, encontros alegres apesar da "morbidez" e complexidade do entorno. Alguns exemplos de metáforas de trabalho durante o ensaio das cenas:

\footnotetext{
${ }^{9}$ Verificar o artigo da autora intitulado "O funcionamento da atenção no trabalho do cartógrafo", no livro Pistas do método da cartografia, organização de Eduardo Passos, Virgínia Kastrup e Liliana da Escóss (2010).
} 
[Para duas atrizes, dentro da caçamba de lixo]: Pensei em trabalhar no início com animais, tipo barata! [Ri muito...]

[Para uma das atrizes, sobre uma cena em que a personagem vive uma dúvida existencial ]: O que fiz na minha vida até agora? Fiz tudo o que eu queria mesmo? Eu podia estar lá no Teatro Abril, tô aqui no Bom Retiro, fazendo essa pecinha... Você tá casada com o homem certo? Qualquer dúvida assim. [Todos riem.]

[Para as atrizes que fazem manequins jogadas fora, quebradas, numa caçamba]: Muita manequim pior por aí, a gente tá bem! Tanta gente com câncer. A gente tá bem.

[Para outra atriz, que faz a "guia-fantasma" do teatro]: A ideia é que você durma no teatro, de um dia para o outro, pra viver essa experiência do fantasma! [E ri...].

[Para um coro de atores]: O musical da cracolândia deu um salto. Antes tava pior do que balé de final do ano de escola! [Ri...].

(Anotações minhas das provocações de Antônio Araújo em diário de campo. Em colchete e itálico = observações minhas).

Vejamos um comentário de Antônio Araújo sobre sua forma de falar com os atores em ensaios ou após apresentações:

Eu fiz isso com um ator na semana passada: "nossa, mas você está aqui no espetáculo? Achei que você não veio hoje, só seu corpinho veio". Brincando, às vezes eu gosto de... eu não quero transformar isso numa [...] crise. Ele falou "não, você acha?", eu falei "acho, veio só seu corpinho. Será que dá pra vir inteiro amanhã? Não sei, se der seria bom, né?". Aí a pessoa ri, acha "tá bom, vamos ver". (Entrevista concedida por Antônio Araújo, 2012).

Tó (Antônio Araújo), como é chamado e conhecido, com essas provocações, acaba instaurando um clima entre ironia e humor negro que causa, também, uma descontração no ambiente, gerando, como consequência, um certo "alívio" nos atores que, às vezes, acabam tensos no processo de criação, que é sempre lugar de crise, como ele mesmo gosta de afirmar. Os atores chegam para ensaiar já muito cansados do dia inteiro de trabalho, às vezes dando aulas ou trabalhando em outras áreas que não de teatro. A atmosfera do bairro do Bom Retiro e o teatro abandonado onde ensaiavam, somado ao fato do horário, pareciam contribuir para um desgaste. Porém, brincadeiras como essas, do diretor, e a colaboração concomitante e paralela entre muitos criadores, de diferentes áreas (luz, som, figurino, cenário, dramaturgia etc.), construía, paradoxalmente, um espaço de ebulição criativa.

Isso causa já um outro estado, diferente, por exemplo, do contexto da montagem de Os bem intencionados, no Lume Teatro, que começava sempre de manhã cedo e ia até à tarde, em um bairro de Barão Geraldo, Campinas, com silêncio ao redor, árvores, casas. Grace Passô, ao dirigir o espetáculo do Lume, às vezes demonstrava, também, um humor "sarcástico":

A gente vai fazer a mesma coisa que a gente fez, os mesmos movimentos, partituras etc., a mesma improvisação. [...] Se alguém tiver o erro terrível de errar o movimento, improvisa. (Trecho de indicação de Grace Passô, 2012. Minhas anotações em diário de campo. Grifo meu.). 
Voltando ao contexto do workshop da Familie Flöz: um mosteiro no meio da Toscana, plantação de lavandas nos arredores, burrinhos pastando, árvores, ar puro, água de nascente... Outras formas de forças na composição dos agenciamentos e afetos. A instalação, nos primeiros momentos e dias, de um ambiente de brincadeira, fluido, divertido, diminuía a expectativa e ansiedade dos alunos e favorecia a entrega ao presente. O clima de jogo e não seriedade não se confundia, no entanto, com falta de responsabilidade, dedicação e rigor nos exercícios. Uma atmosfera diferente contagiou aquele espaço, um misto de comunidade, parceria, relações de confiança e muito prazer em cada momento.

Poderíamos supor que essa seria uma boa estratégia planejada para conquistar os alunos e, em seguida, partir para um trabalho diferente, no qual novamente apareceria o ambiente competitivo e crítico que muitas vezes permeia workshops, causando bloqueios e evidenciando incapacidades. Mas não era o caso, pois, ao entrevistar os atores do grupo, vi que o prazer é um item valioso que guia escolhas dramatúrgicas e norteia o trabalho de um modo geral. As cenas só são mantidas na criação de um espetáculo, por exemplo, se as pessoas que as realizam estão felizes com elas. Cenas são jogadas fora caso isso não aconteça, ou deixe de acontecer. Ou atores são substituídos, caso outro (da companhia), aceite atuar em uma parte que alguém não quer mais.

É um acordo básico, ninguém tem que fazer algo que não quer. E se ele não quer fazer ele pode dizer "Eu não quero mais fazer. Estou fora dessa cena. Eu não gosto dessa ideia". E isso faz sempre algo novo, sempre abre uma nova porta, mas talvez cause prazer, ou torne o trabalho mais duro, o que também provoca prazer. ${ }^{10}$ (Entrevista concedida por Michael Vogel, julho de 2012).

O olhar para os desafios como "novas portas que se abrem", como oportunidades para crescimento, demonstra ser um ato inteligente na criação artística. Já no primeiro dia de trabalho, os atores da companhia nos passaram aquilo que denominam de "princípios da Familie Flöz". Vou me permitir escrevê-los sem traduzi-los, na exata forma como escutei, pois creio que, nesse caso, as palavras em inglês podem revelar um sentido mais abrangente. Os princípios são os seguintes:

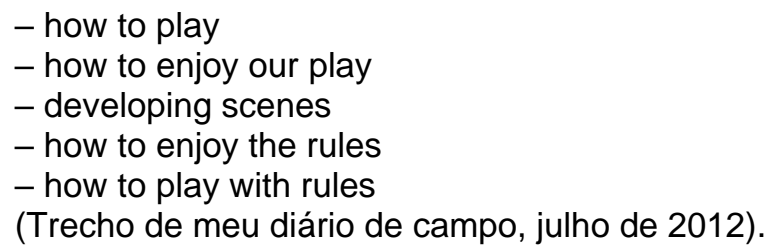

\footnotetext{
${ }^{10}$ Tradução minha: It's a basic agreement, nobody have to do something that he don't want to do. And if he don't want to do he can say "I don't want to do, anymore. I'm out on this scene. I don't like this idea". And this makes always a new, opens always a new door, but maybe makes pleasure, or maybe makes a hard work, what also makes pleasure.
} 
A ideia era transmitir aos alunos os fundamentos de trabalho que regem o cotidiano do grupo, a maneira de se relacionar e resolver problemas. Nesse sentido, a ideia de uma convivência integral entre participantes e professores (nas aulas, no lazer, na alimentação, no tempo livre), ressoava como uma experiência complementar e, ao mesmo tempo, essencial ao que era desenvolvido nos exercícios. Sim, porque na invisibilidade e nas entrelinhas existem e, são trocadas, condutas, posturas e modos de ser, que influenciam diretamente o criar.

Podemos notar nos princípios elencados acima que a palavra enjoy aparece duas vezes em cinco frases: no como desfrutar, ter prazer, apreciar, divertir-se, fruir - a peça, ou cena, exercício, jogo; e como se divertir com as regras. É curioso pensarmos que a palavra play pode significar tanto peça (de teatro), como jogar e brincar. Então, conseguimos observar como, de fato, o prazer do fazer e, a própria brincadeira, estão na base de pensamento e planejamento das práticas de trabalho. Não basta saber como atuar (how to play), mas, logo em seguida, como ter prazer em atuar (how to enjoy our play). Assim como não basta saber como jogar, ou improvisar com regras (how to play with rules), mas também como ter prazer com as regras (how to enjoy the rules).

As provocações e metáforas de trabalho no workshop não nos ensinaram como ter prazer com as regras ou como ter prazer em atuar, pois isso é singular para cada um, a água ninguém pode fornecer (BARBA, 1984) ${ }^{11}$. Mas, o fato de atentarem para isso a todo momento e, ao mesmo tempo, criarem condições para que o prazer de brincar, de jogar, pudesse acontecer, influenciava a construção de uma atmosfera descontraída favorável à diversão, mesmo que com regras claras.

Se pensarmos a arte do teatro, podemos imaginar uma encenação como a criação de um ambiente que pode potencializar o encontro. O que será gerado a partir desse encontro, é sempre uma questão de risco e experimentação. Nada se garante, mas poderíamos arriscar dizer, que as produções teatrais buscam criar uma atmosfera para um encontro alegre, no sentido espinosano, encontro este que pode gerar, em última instância, potência de vida naqueles que o partilham. Como podemos verificar de forma clara em Pélbart (2006):

\begin{abstract}
Somos um grau de potência, definido por nosso poder de afetar e de ser afetado, e não sabemos o quanto podemos afetar e ser afetados, é sempre uma questão de experimentação. Não sabemos ainda o que pode o corpo, diz Espinosa. Vamos aprendendo a selecionar o que convém com o nosso corpo, o que não convém, o que com ele se compõe, o que tende a decompô-lo, o que aumenta sua força de existir, o que a diminui, o que aumenta sua potência de agir, o que a diminui, e, por conseguinte, o que resulta em alegria, ou tristeza. Vamos aprendendo a selecionar nossos encontros, e a compor, é uma grande arte. (PELBART, 2006).
\end{abstract}

\footnotetext{
11 É comum escutarmos que a técnica pode construir recursos corporais e repertório físico, porém, aquilo que dá vida à técnica não poderá nunca ser apreendido ou ensinado, sendo uma questão pessoal. Como diz Barba (1994, p. 74): "Aqui estão os canos, canais, alguma cisterna; tudo seco. A tua água ninguém pode oferecer-te".
} 
No workshop da Familie Flöz, os alunos eram todos atores profissionais, não era um grupo de iniciantes, então, talvez, esse era mais um motivo dos professores buscarem reduzir ao máximo uma cobrança por perfeição e por acertos. O que importava, de fato, era a viver a experiência, potencializar os encontros alegres. E, na maioria das vezes, quando a "préocupação" abre espaço para a experiência, o inusitado pode acontecer: aquilo que sempre se espera e se deseja, ou seja: uma atuação viva, inteira, presente.

Em um determinado exercício, que exigia regras e uma precisão corporal, Michael Vogel estava observando um dos alunos, que demonstrava alguma dificuldade em seguir a proposta e, ao mesmo tempo, estar vivo em cena. Nesse momento, Michael Vogel provocou-o a transgredir:

Sempre siga primeiro a inspiração/imaginação e não as regras de um exercício caso exista um conflito. ${ }^{12}$ (Trecho da provocação de Michael Vogel, 2012. Minhas anotações).

O que isso significava? O aluno realizava o exercício, que de certa forma exigia uma destreza técnica - precisão de pontuação entre início, meio e fim do gesto; foco claro pelo olhar e com o nariz da máscara; tempo de triangulação; indicação de inspirar ao focar uma direção e expirar ao compartilhar com o público, entre outras coisas. Além da proposta do exercício, que era relativamente simples, sem requisitar improvisação na criação ou desenvolvimento de cena, nada era necessário ser feito.

Por outro lado, dentro dessa simplicidade, tudo poderia acontecer, ou seja, o que Michael Vogel dizia em sua provocação era: quando algo te inspirar na imaginação e, para que o fluxo aconteça, precise acarretar na perda de bordas e limites no exercício, causando um conflito interno, transgrida! Subverta! Porque entre um exercício bem realizado somente em seus aspectos formais, tecnicamente, ou um exercício subvertido nas regras, mas pulsante em fluxo de vida, melhor a segunda opção, sempre. Atentos: não estamos criando uma oposição entre técnica e vida, apenas abrindo a percepção para outras possibilidades, para além das regras.

É claro que se tratava de um experimento no decorrer de um curso de formação/aprimoramento e, se fosse o caso, por exemplo, de uma apresentação de espetáculo, a subversão e transgressão de limites no desenho dramatúrgico poderia ser complicada, dependendo da linguagem ou estética do trabalho. Cada caso é um caso. Mas na nossa discussão sobre o território de preparação do ator - que é espaço reservado para erros, crises e experimentações - a provocação para transgredir regras, caso haja um conflito entre a formalidade e o fluxo de vida, parece ser um dispositivo potente.

\footnotetext{
12 Tradução minha do diário de campo: Always follow first the inspiration/imagination but the rules of the exercise if there is a conflict.
} 
A subversão em apresentação de espetáculo, pode, inclusive, acontecer no território micro, na invisibilidade. Se nos colocarmos novos desafios a cada vez que entramos em cena, mesmo que invisíveis aos olhos, mas perceptíveis nas pequenas variações que podemos brincar dentro da estrutura, quem sabe assim possamos abrir espaço para outras potências de fluxo acontecerem?

Muitas vezes, na realização de exercícios, jogos, dinâmicas com regras fixas, acabamos nos atendo à fixidez das normas, esquecendo da possibilidade irrestrita para transgressão, desde que em direção à potência de vida e encontros alegres, de linhas de fuga. Não será justamente nesses momentos que algo inesperado pode acontecer, surgir, se criar? Ir sempre em direção ao limite, além do limite, em busca de intensidade na criação e nas relações entre os corpos. Isso me recorda os anos em que trabalhei no Barracão Teatro (Campinas, SP) e Tiche Vianna e Esio Magalhães se cansavam de repetir, observando cenas, improvisações e ensaios: "Ou intensifica - ou transforma!".

Com a Familie Flöz, como se trata de um curso de atuação com máscaras, a sua utilização no rosto para o desenvolvimento da maior parte das cenas era recorrente. $\mathrm{O}$ uso de um objeto artificial sobre o rosto pode causar diferentes percepções em quem atua e quem assiste. Se, por um lado, pode criar uma sensação de aparente liberdade no atuante, por outro, o expõe de uma maneira ainda mais clara. Ao excluir as expressões faciais e a fala, com máscaras inteiras, o resto do corpo se evidencia, como se estivesse sob uma lupa ${ }^{13}$.

$\mathrm{O}$ ato de cobrir o rosto parece auxiliar, também, no processo das micropercepções. Observo, tanto em meu trabalho como no dos outros, o quanto a autopercepção e a autoconsciência dos mínimos movimentos, se amplia com a utilização das máscaras. Sendo assim, há que se trabalhar, por um lado, com uma precisão muito desenhada e detalhada dos gestos e, por outro, com uma sutileza que caminha por uma linha tênue, que guia cada microimpulso, cada micro-movimento, cada micro-gesto, cada micro-ação. A micropercepção é uma sensação que pode estar relacionada ao detalhe, mas não somente ou necessariamente.

\footnotetext{
13 Verificar, principalmente, o livro O corpo poético: uma pedagogia da criação teatral, de Jacques Lecoq (2010). Embora o tema da atuação com máscaras seja fascinante, não é o foco central dessa pesquisa, portanto, não irei verticalizar a sua especificidade, mas somente citar alguns elementos inerentes aos exercícios do curso, para que se compreenda o contexto. Aproveitando o fato de estar na Europa para fazer o workshop da Familie Flöz, participei, ainda em julho de 2012, em Paris, do Stage Jeu et Masques, na École Internationale de Théâtre Jacques Lecoq, com duração de dez dias, com os professores Paola Rizza e Eric Nesci. O workshop, intensivo, das $9 \mathrm{~h}$ às $18 \mathrm{~h}$, trabalhou com as máscaras neutras, larvárias, expressivas, da comédia humana e da commedia dell'arte; além da confecção de máscaras e preparação corporal, acrobacia, muita improvisação e jogos. Escrevi um diário de campo, no final de cada dia de aula, com a descrição minuciosa de todas as atividades realizadas. Curiosamente, nesse workshop não pude registrar em audio, vídeo, ou mesmo realizar anotações durante as aulas. Os professores diziam que a exigência era estarmos inteiramente presentes sem dividir a atenção com nenhuma atividade, para guardarmos em nossa memória aquilo que realmente importasse das práticas. Por esse motivo, não utilizo na tese nenhuma indicação do workshop da escola Lecoq, embora o conhecimento adquirido faça parte inevitável das minhas elaborações sobre o trabalho com máscara, principalmente. O método de trabalho iniciado por Jacques Lecoq, no início do séc. XX, influenciou e continua influenciando muitas gerações por todo o mundo que trabalham com uma estética de teatro físico ou com máscaras, assim como a Familie Flöz e o meu próprio trabalho.
} 
Vamos ampliar essa possibilidade de discussão, desdobrando ainda mais o território potencial com o qual estamos trabalhando. Para isso, vejamos um exemplo do curso $O$ corpo como fronteira. Renato Ferracini trabalha um exercício em grupo que é de escuta do corpo coletivo: seguir a movimentação/ação do outro sem evidenciar quem começou a modificá-la. O desafio é deixar o corpo pensar por inteiro, não seguindo a movimentação com meus olhos do globo ocular, mas com meu corpo-olho, meu corpo-ouvido, meu corpo-poroso. Vejamos um trecho da proposição do exercício:

Fica numa rodinha. Aí eu vou começar um ritmo no movimento e vamos deixar que isso vá modificando, sendo que eu não posso impor, nem ser muito passivo. Não vou falar muito pra gente ver na prática. Juntos é um só. Vocês são um corpo só. Troca junto. Brinca junto, literalmente. É isso mesmo. Agora aos pouquinhos eu vou me soltando ao mesmo tempo que mantenho minha conexão com o grupo. Vai se soltando do outro ao mesmo tempo que me mantenho conectado. Entra nas pequenas diferenças. Sem se impor. Joga, brinca, sem impor. Pode ir se separando mais, brincando mais com o espaço. Isso. Não é imitar o outro é entrar no jogo que é proposto pelo grupo. E o outro é sempre diferente. Lembra de ir até o fim. Vai intensificando que a coisa muda. Não precisa ser exatamente igual, é a mesma ação mas não é cópia, não importa se está para o meu lado. Sempre fica ligado no todo. É o mesmo território. Presta atenção em qualquer tipo de variação. Não impõe. Brinca que vai modificando. Se joga na brincadeira que a coisa vai. É igual brincar junto, eu não preciso fazer igual. Eu preciso brincar junto. Não é siga o mestre, é o jogo do grupo, não tem nenhum mestre nem nenhum vassalo. (Trecho da provocação de Renato Ferracini em workshop, 2011. Minhas anotações).

Vemos alguns pontos importantes no caso do corpo coletivo, que não deixam de ser os mesmos pontos trabalhados individualmente em outros momentos do curso, porém agora intensificados para que haja uma escuta conjunta. É muito evidente, observando de fora e, ao realizar a prática desse exercício que, quando, mesmo sem querer, nos atentamos demais, a mente começa a se dissociar do resto do corpo e, então, cria-se um lapso de tempo, que mesmo sendo muito pequeno em sua duração, é suficiente para desconectar o coletivo, o todo, o entre.

A qualidade da atenção deve ser levemente, sutilmente, desatenta, descontraída, distraída. "Distraídos, venceremos", já disse Leminski (2003, p. 167), ou "a felicidade se acha é só em horinhas de descuido", diria um dos personagens de Guimarães Rosa (1967, p. 29). É uma linha muito tênue. O espaço do jogo, da diversão, da brincadeira e do prazer, nasce justamente de uma qualidade de atenção microscópica, que tange instantes de micropercepção nos quais conseguimos sentir tudo o que nos acontece, ao mesmo tempo em que conseguimos agir com o que nos acontece. Estamos em busca de uma atenção fina, minuciosa, sem, no entanto, com isso, se tornar rígida. O corpo que brinca é um corpo atento em todos os poros, entregue ao presente, atento ao todo, receptivo e ativo, aberto às forças em fluxo. 
Quando eu falo presta atenção é: sente. Entra no jogo. Se divirtam. Literalmente. Se divirtam com esse estar junto. Isso. Prestar atenção para qualquer coisa que aconteça. (Trecho da provocação de Renato Ferracini em workshop, 2011. Minhas anotações. Grifo meu).

Com a equipe do Projeto Temático Memória(s) e Pequenas Percepções (FAPESP), onde foi desenvolvida essa pesquisa, realizamos um intensivo de atividades, para refletir, na prática, as questões debatidas com os conceitos estudados. Para entender melhor o que seria a micropercepção e como poderíamos caminhar para potencializá-la em nossa prática, realizamos exercícios diversos. Alguns insights me apareciam, discretamente, a partir da experimentação:

Deitamos no chão, espreguiçar muito grande no espaço e de olhos abertos, até os apoios, plano baixo, médio, alto, dinamiza. Energético ${ }^{14}$ e troca com o outro. Como meu corpo está mais cansado! No início estava bem gostoso, mas depois de um tempo, parece que a energia de repente acabou. 30 segundos mais! 5 ! Aí começava de novo... Acho que não consegui reciclar, renovar eu mesma... Parou! Segura. Mais 30 segundos. Aí foi melhor, tinha recuperado um pouquinho. O estado do brincar com o outro estava prazeroso, porém me faltava energia... Parou de novo. Lá dentro. Mais 30 segundos. Parou!

Agora deitamos novamente no chão, com esse estado e novamente começamos a espreguiçar. Aí tudo estava diferente. Sentia cada parte do meu corpo, era mais vivo e melhor meu espreguiçar. Eu via as formas no espaço se desenhando com meu corpo, ao mesmo tempo preenchido de energia pulsante. Dinamizei com essa energia, já um degrau acima, o corpo um pouco mais leve... os dedos das mãos com espaço entre eles, sozinhos, a axila com espaço, sozinha, o olhar dilatava-se sozinho... às vezes se perdia, quando conscientemente, talvez, eu quisesse mudar a direção ou algo assim quebrava o fluxo e automaticamente se refletia no olhar. Não há como mentir. Dinamizamos essa energia, energético novamente. Parou! Agora com tudo dentro, explodir pra fora, muito grande e muito suave. Foi pros meus braços. Eles sozinhos... Foram subindo com suavidade, sem tensão. Minhas pernas bem fixadas no chão. Um tempo isso... Agora parou! Muito tenso dentro, quero me mexer mas não posso. Muita tensão dentro. Isso vazava pra voz e diferentes espasmos quando segurava demais. Força física. Os braços iam. As pernas precisavam de mais. Os pés pendiam pra frente, pro metatarso, que segurava todo o corpo. O corpo estava em certo desequilíbrio e pequenas torções.

Então, transformávamos isso que estava amplo fora, pra bem pequeno dentro, como se raios, pequenos, atravessassem minha coluna e quadril. No início mantive ainda grande, mas depois consegui um pouco internalizar isso. Os pulsos meio homem-aranha, como se dessem e recebessem ao mesmo tempo, os dedos ainda abertos. Indicação em nos movimentarmos a partir do que o outro nos impulsionava a agir, porosos, afetando-nos pelos outros. Sem ter que olhar, sem imitar, sem reagir fortemente, simplesmente escutando os sons, o espaço e os outros. Como isso me afeta?

É muito sutil a variação, a diferença, a transição entre o QUERER FAZER e o DEIXAR SER... Em momentos sentia claramente e organicamente o outro me afetando, simplesmente sua presença e qualidade de energia/movimento/estado. Outras ficava esperando, tentando sentir, aí não funciona. O tentar sentir não funciona. Temos que estar sutilmente desligados, distraídos. Aí sim porosos. Muita

\footnotetext{
14 "O treinamento energético é um espaço no qual o ator passa por uma espécie de desautomatização forçada. $O$ trabalho de treinamento energético busca 'quebrar' as doxas e os vícios no ator para que ele possa dar, senão um livre curso, a possibilidade de aparecimento de pequenos campos de vivência intensiva que, dentro do LUME, chamamos de energias potenciais do ator. Maiores informações em meu livro Café com queijo: corpos em criação". (FERRACINI, 2013, p. 95).
} 
vontade atrapalha. Quando nos surpreendemos... Um pouco distraídos para nos surpreender. O estado de "ligado" demais, quase que prevê e desenha todas as reações. É um entre essa escuta. Quando rola, não há dúvida. Como é que consigo me colocar nesse estado? Como construir? Como manter? É sutil. Bem sutil.

As micropercepções não estão nos pequenos movimentos, estão no todo.

(Trecho de diário de campo sobre minhas sensações anotadas logo após um dia do curso para a equipe do Projeto Temático, em março de 2012).

Com base na minha experiência como atriz em experimentações dos cursos, nas observações de exercícios de atores e nas metáforas de trabalho sugeridas, inúmeros vislumbres são adquiridos com a prática. O estado vivo do ator pode nascer a partir da criação de condições favoráveis no espaço, no tempo, no coletivo e em si mesmo, para que a capacidade de afetar-ser-afetado aumente e uma atenção distraída expanda a percepção, possibilitando assim, instantes de micropercepção.

A micropercepção não parece ser, somente, uma percepção em seu estado microscópico, mas uma percepção mais abrangente do todo, ou seja, da relação entre as forças intra e entre-corpos. Uma percepção mais fina, em outras palavras, mais sutil do todo do qual fazemos parte. O todo em mim e fora de mim, eliminando os limites rígidos entre esses corpos e essas esferas. Não sabemos ao certo, de que matéria é feita essa percepção sutil, não conseguimos distinguir cada mínimo detalhe das forças que a compõe. Mas conseguimos ter a sensação nítida quando ela está presente, pois ela nos acontece, enquanto atuantes ou enquanto público.

As metáforas de trabalho que auxiliam esse processo na experimentação ou ensaio do ator, parecem estar muitas vezes relacionadas a esses fatores expostos de escuta, prazer, atenção-distração, abertura, paradoxos. Não importa qual é exatamente a imagem sugerida, mas sim o que ela provoca nesse caminho de busca de organicidade. Para que a performance dos atores se preencha de vida, a figura do professor/condutor do trabalho permanece instigando os alunos, em processos pedagógicos, nesse processo de confiança do vazio, que favorece um estado de jogo e fluxo.

Para que isso aconteça, é necessário uma indicação potente, um estado de abertura e recepção dos atores, além de todos os outros fatores que influenciam o momento, como as variáveis das forças presentes no encontro (tempo, espaço, temperatura, sons, por exemplo). Não existe uma fórmula para uma boa indicação, uma metáfora de trabalho que seja potente em qualquer contexto. Quando a provocação sugerida atravessa o corpo-mente do ator, é instantânea a transformação em sua ação, consequentemente a criação de presença, como comenta Hajo Schüler, no curso com máscaras:

Quando você toca alguma coisa no ator, pode ser uma coisa muito estúpida, mas de repente a máscara aparece, ela responde ao impulso sugerido de um modo muito orgânico, cria vida. Uma resposta muito direta a um impulso é uma qualidade muito boa para nós. Isso traz a máscara para o presente, nada comanda (o corpo 
ou a mente), é tudo junto. Cria-se presença. (Trecho de comentário de Hajo Schüler após um exercício no workshop da Familie Flöz, anotações minhas, julho de 2012) $)^{15}$.

Quando Hajo Schüler diz que "a máscara aparece", significa, justamente, que cria vida. Hajo Schüler relaciona a organicidade, vida e presença, com o que apontamos em outro momento sobre uma não divisão entre corpo e mente, uma noção de que o todo atua, sem comando de uma parte. Ao mesmo tempo, evidencia que isso pode acontecer com provocações que geram um impulso instantâneo no corpo. A busca por um estímulo que provoque essa integração entre mente/corpo, consciente/inconsciente, dentro/fora e que, ao mesmo tempo, impulsione um estado criativo, imaginativo e "inspirado", como disse Michael Vogel, nos remete, também, às pesquisas de Stanislávski, já no início do séc. XX.

$\mathrm{Na}$ pesquisa do Projeto Temático, iniciamos conjuntamente a releitura das obras de Stanislávski, que continuam sendo atuais em suas inquietações e buscas de reflexão sobre o trabalho do ator e suas práticas de criação. Buscamos ecos e possibilidades de relações entre aquilo que nomeamos de invisibilidade, forças, paradoxos, não-dualismos e micropercepções, com os estudos do encenador e pedagogo russo.Stanislávski, na primeira fase de seu trabalho, pesquisou muito a imaginação com seus alunos/atores no processo que chamou de "psicotécnica", por trabalhar com estados emotivos e mentais. Trabalhava com uma técnica consciente que tinha como objetivo entrar em contato com o subconsciente, ou inconsciente, de onde viria a inspiração, como também parece afirmar a artista plástica Fayga Ostrower:

Pensar na inspiração como instante aleatório que venha a desencadear um processo criativo, é uma noção romântica. Não há como a inspiração possa ocorrer desvinculada de uma elaboração já em curso, de um engajamento constante e total, embora talvez não consciente. (OSTROWER, 1987, p. 72).

Tendo a clareza de que era impossível criar sempre subconscientemente, Stanislávski empregava diversos modos de estímulo à imaginação, como o "se" ou "circunstâncias dadas" (exercícios imaginativos de faz-de-conta), para dar vida a um papel ou situação cênica. $\mathrm{Na}$ primeira fase de seu trabalho, trabalhava-se primeiro conscientemente e de forma imaginativa, para, em seguida, preencher o corpo de ações-físicas objetivas e "verdadeiras".

Essa técnica foi posteriormente aprimorada pelos estudo mais verticalizado nas ações físicas, quando Stanislávski começou a propor o caminho inverso, que ele próprio denominou de "exterior ao interior". No entanto:

A afirmação da opção metodológica via ações não parece sido de fácil aceitação inicial, em sua época. A ideia de que "uma série simples de ações físicas, realísticas,

\footnotetext{
${ }^{15}$ Tradução minha de diário de campo: When you touch something in the actor, can be a really stupid thing, but suddenly the mask comes out, she respond to the impulse in a very organic way, get's alive. Very direct response of an impulse, is a very good quality for us. This takes the mask to the present, nothing leads (head or body), it's all together. Makes presence.
} 
tem a capacidade de engendrar e criar a vida mais elevada de um espírito humano em um papel" (Stanislávski, 1995, p. 250) causava estranhamento até entre os seus atores, já que o próprio diretor, anteriormente, orientava-os a penetrar nas vias do sentimento através da memória afetiva. (NUNES, 2009, p. 31).

O processo de criação e as práticas cotidianas do trabalho do ator estão sempre em busca de manter vivo, orgânico e verdadeiro o que se cria. Para isso, busca-se, muitas vezes, entrar em contato com o mundo não palpável e concretamente explicável, às vezes chamado de inconsciente, subconsciente ou mesmo misterioso. Na arte não podemos (nem devemos) ser controladores de tudo o que experimentamos, já que, para entrar em estados criativos e desconhecidos, precisamos às vezes abrir mão do que já temos assegurado. Como afirma Fayga Ostrower:

O impulso elementar e a força vital para criar provém de áreas ocultas do ser. É possível que delas o indivíduo nunca se dê conta, permanecendo inconscientes, refratárias até a tentativa de se querer defini-las em termos de conteúdos psíquicos, nas motivações que levaram o indivíduo a agir. Além dos impulsos do inconsciente, entra nos processos criativos tudo o que o homem sabe, os conhecimentos, as conjecturas, as propostas, as dúvidas, tudo o que ele pensa e imagina. (OSTROWER, 1987, p. 55).

Neste sentido, o estudo das metáforas de trabalho, não tem a ambição de revelar ou desvendar o estado criativo, nem formular métodos de criação. Desejo, apenas, nos aproximar ainda mais da sala prática de trabalho do ator, buscando observar algumas formas de provocações que potencializam e auxiliam esse processo em direção à organicidade.

Stanislávski, no início de sua obra $A$ preparação do ator, já destaca que "é difícil despertar a vontade criadora, mas matá-la é facílimo" (2010, p. 29). As metáforas de trabalho são utilizadas para ajudar a despertar essa "vontade criadora", além de momentos de micropercepção: algo que mantenha sempre vivo o que se cria. A repetição, manutenção e atualização destes estados requer um trabalho minucioso para que a criação permaneça sempre viva, orgânica e "verdadeira"16: "Outra fonte importante de estímulo emocional é a verdadeira ação física e a crença que se tem nela" (STANISLÁVSKI, 2010, p. 229).

O fato de acreditar, crer integralmente naquilo que estamos fazendo em cena é outro aspecto que auxilia na não divisão entre corpo/mente. Se abrimos espaço para desconfiança na nossa própria ação, automaticamente nos fragmentamos em dois: uma parte que está agindo e realizando a prática e outra que, ao mesmo tempo, duvida de alguma parte do que

\footnotetext{
${ }^{16}$ Sendo professor de teatro e diretor, Stanislávski não pretendia criar teorias científicas, mas auxiliar nos caminhos e processos de criação do ator: "Não me encarregarei de formular uma definição - disse o diretor. - Os sábios que o façam. Posso apenas ajudá-lo a sentir o que é" (STANISLÁVSKI, 2010, p. 198). Por isso tentava brincar com esses mistérios da natureza e conduzir exercícios que auxiliassem os atores a encontrar ao que chamava de verdade, pela imaginação criadora: "Não devemos esquecer o fato de que muitos aspectos importantes das nossas complexas naturezas são-nos desconhecidos e não estão sujeitos à nossa direção consciente. Só a natureza tem acesso a eles. A menos que conquistemos o auxílio dela, teremos de contentar-nos em exercer domínio apenas parcial sobre o nosso complicado aparelho criador" (Ibidem, p. 209).
} 
se faz: ou a qualidade, ou a entrega, ou o prazer. Pensamentos como "está bom o que estou fazendo?" enquanto se realiza uma ação, são capazes de matar imediatamente a potência, inteireza e organicidade do agir.

Se você quer fazer uma criação, você tem que acreditar que você é um criador. Se você tem dúvida, pare. [...]. Nós temos que acreditar que a máscara está aí e que a atriz se foi. E ela tem que acreditar nisso primeiro. Se ela tem um conflito, nós vemos $^{17}$. (Trecho de comentários de Michael Vogel após a realização de um exercício de uma aluna. Anotações minhas de diário de campo).

Não entremos no mérito, nesse momento, de discutir a ausência/presença do ator/atriz quando Michael Vogel diz que "a atriz se foi", devido às problemáticas e debates em torno do teatro performativo ou pós-dramático. Mais importante aqui é o diálogo que observo em relação ao que Stanislávski aponta como "crença na ação física" com o que Michael Vogel diz acima: "se ela tem um conflito, nós vemos". Sim, porque sabemos que um ator em dúvida daquilo que faz, enquanto faz, transparece o conflito para o público. Não há como esconder. Thomas Richards (2012) conta em seu livro que Grotowski também estava sempre atento à crença naquilo que os atores realizavam:

Muitas vezes, Grotowski nos fazia duas perguntas quando analisava o trabalho de alguém. A primeira: O que você entendeu? [...] Segunda pergunta: Você acreditou? (RICHARDS, 2012, p. 39).

Mais uma vez estamos diante da necessidade de uma não divisão, de integração entre a mente e corpo, consciente/inconsciente. Assim, se a atenção é demasiada, excessiva, colada em uma cobrança de si mesmo que se avalia enquanto atua e por isso se divide, acaba por bloquear essa crença, que confia inclusive nos mistérios, no indizível, no incontrolável e imponderável.

Nas práticas de criação e treinamento dos dias de hoje, em alguns dos grupos consolidados de pesquisas continuadas, comumente emprega-se o uso de metáforas de trabalho para estimular o corpo - não dissociado nunca da mente/imaginação - mas, poderíamos observar que, nesses casos, as indicações atuam na movimentação física do ator (mesmo que microscópica), como comentava Hajo Schüler, por exemplo, sobre uma "resposta muito direta ao impulso".

O ator, nestes contextos, não imagina conscientemente e previamente como realizará de forma concreta certa indicação, mas busca permitir que a metáfora de trabalho atue imediatamente numa reação corpórea, sem um modelo correto ou imaginado. Isto não significa, de maneira alguma, que a imaginação, nestes coletivos teatrais atuais, não está

\footnotetext{
17 Tradução minha: If you want to make a creation, you have to believe you are a creator. If you have a doubt, stop. [...] We have to believe that the mask is there and the actress is gone. And she has to believe it first. If she has a conflict, we see.
} 
presente, mas ela atua ao mesmo tempo que a ação, preenchendo-a de forças invisíveis e de fluxo contínuo.

Busca-se, de alguma forma, realizar um processo não racional, não lógico e muitas vezes, inclusive, incoerente e paradoxal para buscar alcançar territórios outros, inimaginados. No entanto, precisamos ressaltar que não queremos deixar margem para uma compreensão equivocada de que um processo dito "não racional" signifique a ausência de consciência ou da mente na investigação prática.

Lembremos: desejamos um olhar sobre o corpo em estado de criação que possa ser entendido como um corpo que também pensa: meu joelho pensa, meu plexo solar pensa, assim como minha mente pensa. Um "entendimento encarnado da mente e a perspectiva de um corpo que pensa" (NUNES, 2009, p. 15). Tudo em fluxo, em alta velocidade e sempre se modificando, sem hierarquias ou comandos do "alto da torre do pescoço"18.

Em procedimentos práticos de trabalhos autorais, por exemplo, os atores partem de caminhos distintos, pois não utilizam textos dramáticos previamente escritos em suas criações. Mesmo no caso de "Os Bem Intencionados", do LUME Teatro, espetáculo escrito pela diretora Grace Passô, a tessitura do texto foi realizada a partir das improvisações. Nesse sentido, cabe-nos observar que formas diferentes de encenações necessitam de caminhos particulares de criação. Uma criação coletiva ou processo colaborativo, como no Teatro da Vertigem, por exemplo, requer uma provocação diferente em relação à montagem de um texto dramático, pronto de antemão. No processo colaborativo a dramaturgia é tecida, pelo dramaturgo, juntamente com o processo, a partir do improviso e do tema sugerido.

O que estamos em busca, entretanto, é um ponto que existe em comum a qualquer forma de criação: uma qualidade e um estado no ator vivo, independentemente do gênero no qual possam ser classificados ou enquadrados. Esta qualidade sugere um estado de presença-orgânica-viva-verdadeira. Ao contrário da divisão ou dualismo que possa existir entre corpo/mente, o trabalho do ator pede um constante ir e vir de fluxos entre o interno e externo (diluindo inclusive as possíveis fronteiras entre esses espaços), em um processo que é, ao mesmo tempo, conduzido e relaxado, consciente e inconsciente, preenchido e vazio. As diferenças no modo ou caminho para se trabalhar o ator, talvez possa ser estritamente relacionada aos distintos gêneros ou linguagens encenadas.

Este tipo de diferença entre linguagens e formas de preparação, já foi observada também na atualidade, em atores brasileiros, pelos pesquisadores Sílvia Fernandes e Mauro Meiches. No livro Sobre o trabalho do ator (1988), os autores descrevem algumas formas de treinamento de atores como Marília Pêra, Antônio Fagundes e Paulo Autran, concluindo que

18 "Plantada na torre do pescoço/ a cabeça, na altura,/ mal percebe nossas inquietações de planície" (ANDRADE, 1996, p.30). 
não existe uma maneira de preparar-se que possa ser melhor ou generalizada para qualquer tipo de teatro:

Para pensarmos em um treino do ator, em uma aprendizagem especificamente teatral que habita um profissional, falar genericamente por meio de categorias não dá conta da diversidade que constitui nossa cena. Um treino pode ser um aprendizado conjunto do uso da voz, do corpo, um estudo detalhado de dramaturgia, como pode ser também o despir-se de freios e convenções que tornam a expressão algo estritamente construído. Sua variação de qualidade forma sua possibilidade de diferenciação. (FERNANDES; MEICHES, 1988, p. 164).

Novamente notamos a indicação de um treinamento expandido, que, desde Stanislávski e Grotowski, quando propunham aos atores estarem em seu cotidiano conectados com a arte que realizavam e abertos à percepção de seus corpos nas atividades do dia-a-dia, até os dias de hoje, quando o significado de uma preparação/treinamento pode abranger diversos dispositivos possíveis.

É uma relação íntima e ética com o vínculo ao próprio trabalho, não só no momento da criação, mas nas composições incessantes de formas de existir e resistir, re-existir. As infinitas possibilidades estéticas em gêneros teatrais irão necessitar de caminhos particulares de preparação do ator, que podem ter pontos comuns com outros, mas serão sempre singulares:

A diferença entre esses atores reside na função que passam desempenhar em cada teatro. Em um, a serviço de uma representação, o ator interpreta uma personagem e isso requer dele uma eficácia bastante determinada. Noutro em causa própria, o ator interpreta a si mesmo na representação. Em um terceiro, podemos pensar o ator como um intérprete do mundo. Ele não se coloca transparentemente em cena mas também não se oculta inteiramente numa vida de ficção. Ele almeja transformar-se em um sentimento coletivo, comum a muitos e por isso não personificado em ninguém. (FERNANDES; MEICHES, 1988, p. 167).

De qualquer forma, poderíamos afirmar que independentemente de gêneros, estéticas ou linguagens teatrais, a preparação do ator e manutenção desta preparação pela repetição/atualização nas apresentações e espetáculos, está sempre preocupada fundamentalmente com a organicidade das expressões do corpo artista. É aqui que reside essa pesquisa. Nas metáforas de trabalho que estão, inevitavelmente, sempre em busca de vida, potência de vida na performance do atuante.

Como desejo estar demonstrando ao longo dessa nossa conversa, estudar este campo do trabalho do ator (para além das diversidades técnicas), é buscar compreender, potencializar ou problematizar, um mundo de forças invisíveis, virtuais, microperceptivas. Queremos discutir as forças invisíveis que precorrem o corpo, não sendo este assunto nenhuma novidade, pois Stanislávski já buscava provocar seus atores neste mesmo território invisível: 
Que nome podemos dar a essa corrente invisível que usamos para nos comunicar uns com os outros? Algum dia esse fenômeno será objeto de pesquisas científicas. Por ora, vamos chamá-los de raios. E agora vejamos o que se pode descobrir sobre eles pelo estudo e também anotando as nossas próprias sensações. (STANISLÁVSKI, 2010, p. 253).

Ao mesmo tempo, o que chamamos de forças e Stanislávski nomeia de "raios", Michael Vogel expressa como um aparente "nada", porque não visível, mas perceptível:

Se você não vê, isso acontece dentro... Nós somos animais, então nós podemos sentir isso. Nós trocamos isso com o público. Esse "nada" não é "nada". ${ }^{19}$ (Trecho de fala de Michael Vogel. Anotações minhas em diário de campo).

As metáforas de trabalho são utilizadas na tentativa de pressionar essas forças invisíveis no nível da micropercepção, na hipótese de que seja um caminho possível para a criação e atualização de organicidade nas matrizes físico-vocais. Embora não tenhamos clareza racional das micropercepções, não podendo traduzi-las em palavras, elas existem e nos afetam a todo instante.

No cotidiano é comum estarmos mais atentos às maiores percepções - macro - que são claramente traduzíveis e entendidas de um modo lógico, pois a compreendemos quando realizamos síntese de consciência. Existem momentos, porém, em que percebemos, macroscopicamente, um sentido de algo que vivemos, mas, microscopicamente, outro, não facilmente explicado. Essa complexidade se deve ao fato de que nosso ouvido e nossa visão captam o instantâneo e o "óbvio" de uma forma clara, enquanto, ao mesmo tempo, todo o resto do nosso corpo pode microperceber outros fenômenos, mesmo que o lógico possa ser, talvez, aparentemente incoerente.

As metáforas de trabalho são empregadas na intenção de ampliar e potencializar essas micropercepções, na eterna busca de presença no trabalho do ator. Stanislávski parecia discutir sobre esse mesmo estado de micropercepção quando se refere às "antenas emocionais":

Você nunca dirigiu suas antenas emocionais para sondar a alma de outra pessoa? Olhe atentamente para mim, tente compreender e captar meu estado de espírito. Sim, assim mesmo. Diga-me agora como me acha. (STANISLÁVSKI, 2010, p. 241).

Em outro momento, quando discorre sobre o inconsciente, Stanislávski parece também estar tratando deste território invisível e microperceptível, que modifica e potencializa o estado do corpo expressivo:

Quando atinge a região de subconsciente, abrem-se os olhos de sua alma e ele se percebe de tudo, até de ínfimos detalhes, e tudo aquilo adquire um significado

\footnotetext{
19 Tradução minha: If you don't see, it happens inside... We are animals, so we can feel it. We change this with the public. This "nothing" is not "nothing".
} 
totalmente novo. Tem consciência de novos sentimentos, concepções, visões, atitudes, tanto no papel como em si próprio. (STANISLÁVSKI, 2010, p. 335).

Independentemente de utilizar ou não as mesmas palavras, ou termos, ou conceitos, para pensar sobre este estado potencializado e ampliado de percepção, de atenção, a revisão da obra de Stanislávski, tem demonstrado ser enriquecedora para nossas reflexões. Stanislávski utilizava diversas metáforas para descrever situações análogas às que queria explicar sobre o trabalho do ator. Essa atitude era recorrente e parecia esclarecer de forma ampla algumas discussões para os atores. Tudo em função de uma "verdade" cênica. Atualmente, pensamos as metáforas de trabalho como imagens potentes para alcançar estados de organicidade. Não se trataria, portanto, do mesmo propósito?

A partir do exposto e dos exemplos apresentados, vimos como uma "atenção distraída", e a noção do brincar a sério, podem ser uma chave para se trabalhar o trânsito entre consciente e inconsciente ou a integração entre mente e corpo. Nesse mesmo sentido, procuramos vasculhar um pouco mais o território invisível das micropercepções, na busca de um entendimento ampliado, que abarque não só o universo micro, mas uma percepção do todo, sensações de conexão entre os corpos, relações contínuas, mutáveis, instáveis e não divisíveis ou apartadas umas das outras.

Assim, vasculhamos alguns exemplos de possibilidades de provocação de estados de presença, onde a noção de uma atenção distraída busca compreender aquilo que acontece no corpo-mente do atuante e que caminha sempre em um limiar muito tênue, repleto de forças instáveis e do imponderável. Nesse sentido, a necessidade do cultivo de um estado de disponibilidade para brincar com essas forças, se torna fundamental para a vida e presença cênica.

\section{Referências}

ANDRADE, Carlos Drummond de. Farewell. Rio de Janeiro: Record, 1996.

ARAÚJO, Antonio. A gênese da vertigem: o processo de criação de "O Paraíso Perdido". São Paulo: Perspectiva; Fapesp, 2011.

ARTAUD, Antonin. O teatro e seu duplo. São Paulo: Martins Fontes, 1999.

BARBA, Eugenio. A canoa de papel: tratado de antropologia teatral. São Paulo: Hucitec, 1994.

FABIÃO, Eleonora. Corpo cênico, estado cênico. Revista Contrapontos. Disponível em: http://siaiweb06.univali.br/seer/index.php/rc/article/view/2256. Acesso em: 15/10/2012.

FERRACINI, Renato. Ensaios de atuação. São Paulo: Perspectiva; Fapesp, 2013.

Café com queijo: corpos em criação. São Paulo: Aderaldo \& Rothschild; Fapesp, 2006.

GIL, José. Abrir o Corpo. In: FONSECA, Tania Mara Galli; ENGELMAN, Selda (org.). Corpo, arte e clínica. Porto Alegre: Editora da UFRGS, 2004.

HORTÉLIO, Lydia. Brincar é o último reduto de espontaneidade que a humanidade tem. Pátio Educação Infantil, v. I, n. 3, dez. 2003/mar. 2004. 
LECOQ, Jacques. O corpo poético: uma pedagogia da criação teatral. São Paulo: Senac São Paulo; SESC SP, 2010.

LEMINSKI, Paulo. Toda poesia. São Paulo: Companhia das Letras, 2013.

LEWINSOHN, Ana Caldas. O ator brincante: no contexto do Teatro de Rua e do Cavalo Marinho. 2009. 164 p. Dissertação (mestrado) - Universidade Estadual de Campinas, Instituto de Artes, Campinas, SP.

. Metáforas de trabalho no território de criação: provocações do corpo-em-arte na preparação do ator. 2014. 346 p. Tese (doutorado) - Universidade Estadual de Campinas, Instituto de Artes, Campinas, SP.

O paradoxo incorporado nas práticas de atuação. Portal Abrace. 2016.

. The Life-Death Paradox in the Presence of the Actor. Performance and Mindfulness. 2(1). Universidade de Huddersfield, 2019.

MOTTA LIMA, Tatiana. Palavras Praticadas: o percurso artístico de Jerzy Grotowski: 1959-1974. São Paulo: Perspectiva, 2012.

MEICHES, Mauro; FERNANDES, Silvia. Sobre o trabalho do ator. São Paulo: Perspectiva, 2007.

NUNES, Sandra Meyer. As metáforas do corpo em cena. São Paulo: Annablume; UDESC, 2009.

OHNO, Kazuo. O Dançarino do Invisível. Entrevista por Irion Nolasco. Disponível em:

http://grupotempo.com.br/tex_kazuo.html

OSTROWER, Fayga. Criatividade e processos de criação. Rio de Janeiro: Vozes, 1987.

PELBART, Peter Pál. A vida Desnudada. In: GREINER, Christine; AMORIM, Claudia (org.). Leituras da Morte. São Paulo: Annablume, 2007.

PEREIRA, Maria Amélia. Derrubaram os últimos jardins para construir prédios. Linhas Críticas, Brasília, v. 8., n. 14., jan./jul. 2002.

RICHARDS, Thomas. Trabalhar com Grotowski as ações físicas. São Paulo: Perspectiva, 2012.

ROLNIK, Suely. Cartografia sentimental: transformações contemporâneas do desejo. Porto Alegre: Sulina; Editora da UFRGS, 2011.

ROSA, João Guimarães. Tutaméia. Rio de Janeiro: José Olympio, 1967.

STANISLÁVSKI, Constantin. A preparação do ator. Rio de Janeiro: Civilização Brasileira, 2010.

UNO, Kuniichi. As pantufas de Artaud segundo Hijicata. In: GREINER, Christine; AMORIM, Claudia (org.). Leituras da morte. São Paulo: Annablume, 2007.

VIVEIROS DE CASTRO, Eduardo. O nativo relativo. Mana, v.8, n.1, p.113-148, abr. 2002.

\section{Vídeo}

CASTRO, Eduardo Viveiro de. A morte como quase acontecimento. Disponível em: http://www.cpflcultura.com.br/2009/10/16/integra-a-morte-como-quase-acontecimento-eduardoviveiros-de-castro/. Acesso em: 09/10/2013.

\section{Entrevistas}

Entrevista com Antonio Araújo (Teatro da Vertigem), realizada em outubro de 2012 em São Paulo (SP), por Ana Caldas Lewinsohn.

Entrevista com Carlos Simioni (LUME TEATRO), realizada em março de 2013 em Campinas (SP), por Ana Caldas Lewinsohn.

Entrevista com Hajo Schüler (Familie Flöz), realizada em julho de 2012 na Toscana, Itália, por Ana Caldas Lewinsohn. 
Entrevista com Grace Passô, realizada em março de 2012, em Campinas (SP), por Ana Caldas Lewinsohn.

Entrevista com Michael Vogel (Familie Flöz), realizada em julho de 2012 em Toscana, Itália, por Ana Caldas Lewinsohn. 